TECHNICAL DIVISION

SAVANNAH RIVER LABCRATORY

MEMORANDUM
DPST $-83-590$

CC: H. R. Stevens, SRL

E. L. Albenesius

J. A. Stone

O. A. Towler/J. R. Cook

W: L. Marter

M. V. Kantelo

C. M. King

S. B. Oblath

J. P. Ryan, Jr.

SRL Record Copy (4)

June 15: 1983

ACC.NO. 104004

TO: J. R. WILEY

EROM: R. H. HAWKINS ( 3 )

TIS FILE RECORD COPY

\title{
MOBILITY OF ${ }^{129}$ I IN BURIED WASTE
}

\section{INTRODUCTION AND SUMMARY}

To quantify the potential for 129 I to migrate from buried waste at the Savannah River Plant (SRP) burial ground, a four year study was made. Spent berl saddles containing $68.7 \mathrm{mci}$ of ${ }^{129} \mathrm{I}$ from separations process air filters were buried in a $10 \mathrm{ft} . \times 10$ ft. $x 12$ ft. deep lysimeter exposed to normal weather conditions at the burial ground. During the four year study leaching and migration released $48.5 \mathrm{nC} i$ of $129 \mathrm{I}$ from the $68.7 \mathrm{mCi}$ buried in the lysimeter. This represents an average $1.77 \times 10^{-7}$ fraction/year released. The release rate was relatively constant during the four years, varying mainly with seasonal rainfall. Calculations based on these results indicate a release of $<3 \mu \mathrm{Ci} / \mathrm{year}$ of $129 \mathrm{I}$. from SRP buried waste to the groundwater. Qualitatively this release and subsequent migration has recently been confirmed by measurement of $0.25 \mathrm{pCi} 129 \mathrm{I} / \mathrm{l}$ in water from a well $600^{\prime}$ southwest of the burial ground.

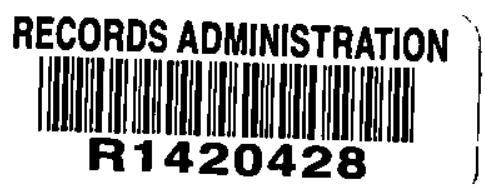


Most ${ }^{129}$ I in the burial ground is on spent berl saddies. The total volume of this waste is approximately. $40 \mathrm{ft}^{3} /$ year, and it comes from the separations areas packaged in drums and segregated from other waste. Because the waste volume is small, and because 129 I has a very long half-life and significant mobility after burial, as reported here, it is recommended that the SRP practice of burying $129 \mathrm{I}$ waste be re-examined. Viable alternatives are Greater Confinement Disposal (GCD) burial, or retrievable storage followed by eventual disposal in a geological repository such as is planned for TRU waste. The latter alternative is consistent with. the TRU waste classification requirements in DOE Order 5820, Chapter II.

\section{BACKGROUND}

Curies of 129 I Buried at SRP

Nuclear fuel processing at the two SRP chemical separations areas is the principal source of $129 \mathrm{I}$. Cornman (1) estimated that $39 \mathrm{Ci}$ of $129 \mathrm{I}$ had been produced at SRP through 1974, of which $20 \%(7.8 \mathrm{Ci})$ was released to the atmosphere and $30 \%(11.7 \mathrm{Ci})$ was stored as solid waste at the burial ground. The yearly total curies of $129 \mathrm{I}$ sent to the SRP burial ground have not been reported, but the yearly SRF releases to the atmosphere have been. Atmospheric releases of $129_{I}$ at SRP for the period 1975-82 were $1.24 \mathrm{Ci}(2)$. Assuming that the earlier distribution between burial ground and atmospheric releases remains valid, then $1.86 \mathrm{Ci}$ of $129 \mathrm{I}$ were stored at the burial ground during the period 1975-82. Thus a total of $11.7+1.9$ or $13.6 \mathrm{Ci}$ of $129 \mathrm{I}$ are estimated to have been stored at the burial ground through 1982 .

Wasteform of ${ }^{129}$ I In The Burial Ground

Essentialy all of the ${ }^{129} \mathrm{I}$ at the burial ground has been stored there on Berl saddles from process air filters. These filters, each containing approximately $20 \mathrm{cu}$ ft of Berl saddles initially coated with $\mathrm{AgNO}_{3}$, have been used throughout the operating history of SRP to remove radioiodine from process air at the two chemical separations areas.

When a spent charge of Berl saddles is first removed from air filter service, radioiodine isotopes other than $129 \mathrm{I}$ predominate. Practice has been to store the spent charges in closed metal drums at the separations facilities for twelve months or longer. This allows decay of the shorter-lived radionuclides and reduces radiation exposure to personnel in handing. At the burial ground the Berl saddles are buried, without containment or 
encapsulation, in waste trenches designated for Intermediate-Level Beta-Gamma waste. At least 48 spent charges of Berl saddles had been buried through $1980(3,4)$ with an average ${ }^{129} \mathrm{I}$ content of approximately $275 \mathrm{mCi} /$ charge.

\section{LYSIMETER STUDY OF ${ }^{129}$ I MOBILITY}

To measure the mobility of 129 I from buried waste under actual SRP burial ground conditions, a lysimeter study was made. It consisted of burying two spent charges of Berl saddles in a lysimeter exposed to natural rainfall and weather in the SRP burial ground. Rainwater that percolated through the soil and the buried Berl saddles to the lysimeter sump was collected and analyzed for $129 \mathrm{I}$.

The lysimeter, shown in Figure 1, was a $10 \mathrm{ft} \times 10 \mathrm{ft}$ x $12 \mathrm{ft}$ deep excavation lined with an open top, $20 \mathrm{mil}$-thick, PVC bag. The PVC liner was slightly larger in all dimensions than the excavation to allow slack and prevent stresses that might tear it. A layer of gravel 18 inches deep was placed in the bottom of the lysimeter to provide a porous sump, and a submersible electric pump was installed there. The pump power cable and discharge line extended to the surface for on-off control and water sampling and removal. A three-ft-deep layer of burial ground soil was placed on top of the gravel.

Two spent charges of Berl saddles, one from F-Area and one from $\mathrm{H}$-Area, totaling $42 \mathrm{cu} \mathrm{ft}$ were placed on the soil layer in the lysimeter on 4/14/76. Analyses for $129_{\mathrm{I}}$ indicatea $68.4 \mathrm{mCi}$ in the F-Area charge and $0.3 \mathrm{mCi}$ in the H-Area charge, for a total of $68.7 \mathrm{mci}$ of $129 \mathrm{I}$ in the lysimeter. Approximately eight feet of backfill soil were placed over the Berl saddles, filling the lysimeter to grade. A low earth berm was constructed surrounding the lysimeter to insure that rain falling on the lysimeter surface infiltrated the soil and to divert other surface water.

Operation consisted of pumping and measuring the percolate water from the lysimeter sump weekly and retaining a monthly composite of it for $129 \mathrm{I}$ determination. The method used for determination

of 129 I achieved high sensitivity through the use of ion exchange, combustion, neutron activation, chemical separation and counting with a $\mathrm{Ge}(\mathrm{Li})$ detector.* The study was terminated in its

ऋ The author acknowledges with appreciation the work Thomas J. Anderson, Martti V. Kantelo and Burton Tiffany of the Savannah River Laboratory in developing a sensitive method to determine the concentration of $129^{\prime}$ in water and for making the determinations on numerous water samples from the lysimeter. 
fifth year (mid-1981) when an absence of percolate water indicated a leak in the lysimeter liner.

\section{RESULTS AND DISCUSSION}

The release curve for ${ }^{129} \mathrm{I}$ on the buried Berl saddles is shown in Figure 2. The data show that a low concentration of $129 \mathrm{I}$ was present in the earliest percolate water collected from the lysimeter sump after the Berl saddles were buried. And similar low concentrations of $129 \mathrm{I}$ continued in the water throughout the four years of the study. Variations in the release rate are attributed to seasonal fluctuations in rainfall amounts with resulting variations in leaching and the volume of percolate water collected.

The data indicate that infiltrating rainwater leached and transported only a small fraction of the $129 \mathrm{I}$ buried in the lysimeter. As shown in Figure 2, the average fraction released was only $1.77 \times 10^{-7}$ /year. The presence of $129 \mathrm{I}$ in the earliest percolate water collected after the berl saddles were buried, and its continuing low concentration in the percolate water throughout the study period, suggest low solubility of the 129 I on the Berl saddles but high mobility through the soil of the small dissolved fraction.

The chemical form of 129 I on the Berl saddles was not determined. However, the saddles carry a coating of silver nitrate when they begin air filter service. Off-gas radioiodine in process air is believed to react with the silver nitrate and to be retained as silver iodide. Therefore, $129 \mathrm{I}$ on the buried Berl saddles probably occurs as silver iodide.

The solubility of silver iodide is $2.8 \times 10^{-6} \mathrm{~g} / \mathrm{L}$ in cold water (5), the specific activity of $129 \mathrm{I}$ is $1.766 \times 10^{-4}$ $\mathrm{Ci} / \mathrm{g}(6)$, and the $129 \mathrm{I} / 127 \mathrm{I}$ ratio in the lysimeter percolate water was $2.5 \times 10^{-3}$ (11). Based on these data, a saturated aqueous solution of AgI in which 0.258 of the iodine is 129 would have an iodine content of $1.5 \times 10^{-6} \mathrm{~g} / \mathrm{i}$ and would contain $6.8 \times 10^{-13} \mathrm{Ci} / \mathrm{L}$. Concentrations of $129 \mathrm{~T}$ in the lysimeter percolate water ranged from $5.0 \times 10^{-12}$ to $5 \mathrm{x}$ $10^{-13} \mathrm{Ci} / \mathrm{L}$. This represents close agreement with the assumed solution and gives strong support to the apparent low solubility of $129 \mathrm{I}$ on buried Berl saddles and the high mobility through the soil of the small dissolved fraction.

Groundwater samples from several wells in and around the burial ground are being analyzed for $129 \mathrm{I}$, but results at this writing are available for only one. This well, PDQ5, located in the groundwater flowpath some $600 \mathrm{ft}$ south of the west end of the 


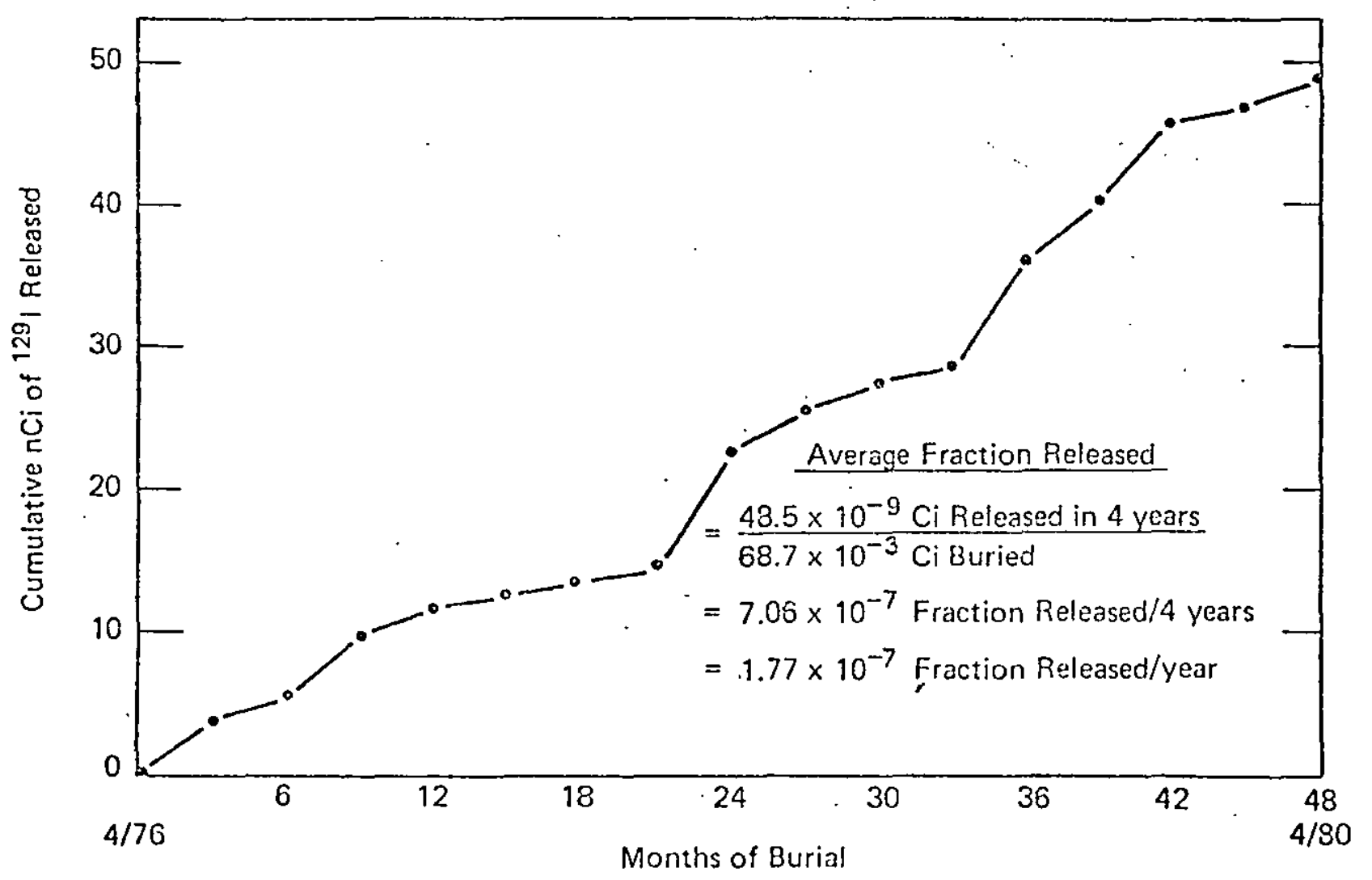

FIGURE 2. Release of ${ }^{129}$ I from Berl Saddles Buried in a Lysimeter. 
643-G burial ground, showed a $129 \mathrm{I}$ concentration of $0.25 \mathrm{pCi} / \mathrm{L}$ (7), or about $25 \%$ of the EPA Primary Drinking water Limit. Thus leaching and subsequent migration of iodine, as predicted from the lysimeter tests, appears to be confirmed.

\section{RECOMMENDED ACTION}

To eliminate the potential for release to the environment of

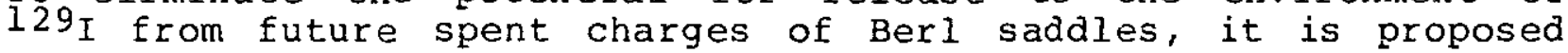
that the current practice of their shallow land burial be terminated. As a preferable alternative, we recommend that the approximately $40 \mathrm{cu} f t / y r$ of berl saddles now being sent to the burial ground be consigned to Greater Confinement Disposal (GCD) burial (8), or to retrievable storage for eventual disposal in a geologic repository. The latter alternative would be a small scale, straight forward extension of present TRU waste practice. $(9,10)$ Either of these offers better retention and control of 129 I than does the present disposal.

This recommended upgrading of $129 \mathrm{I}$ waste disposal is in keeping with the SRP objective to minimize all releases of radioactivity to the environment. It appears justified by the very long half-life and persistence of $129 \mathrm{I}$ if released to the environment.

RHH : ske

Disc 2 


\section{REFERENCES}

1. Cornman, W. R., Estimation of ${ }^{129} \mathrm{I}$ Distribution in SRP Separations Processes. Report no. DPST 74-533, Savannah River Laboratory, Aiken, SC. 1974.

2. Environmental Monitoring in the Vicinity of the Savannah River Plant, Annual reports for years 1975 through 1980 . Reports DPSPU 75-30-1 through DPSPU 82-30-1, Savannah River Plant, Aiken, SC, 1975 through 1982 .

3. Personal communicaticn, Chostner, D. F., Separations Technology Dept., Savannah River Plant, Aiken, SC. 1980.

4. Personal communication, Pickett, C. E., Separations Technology Dept., Savannah River Plant, Aiken, SC. 1980.

5. Handbook of Chemistry and Physics, 56th edition, CRC Prass, Cleveland, OH. 1975.

6. Accountability Manual, DPSOP 23-11, Rev. 11/79, Savannah River Plant, Aiken, SC. 1979.

7. Personal communication, Oblath, S. B., Waste Disposal Technology Division, Savannah River Laboratory, Aiken, SC. 1983.

8. Towler, O. A. and Cook, J. R., Greater Confinement Disposal Demonstration. Report no. DPSTD-83-78, Savannah River Laboratory, Aiken, SC. 1983.

9. TRU Waste Acceptance Criteria for the Waste Isolation Pilot Plant. Report no. WIPP-DOE-069-Rev. 1. Westinghouse Electric Corp. 1981 .

10. Department of Energy (ERDA) Manual, Chapter 0511. 1973.

11. Memorandum, M. V. Kantelo to N. L. Kolb, Savannah River Laboratory, Aiken, SC. April 6, 1981. 